\title{
Analysis of defects and their impact on the production losses using Pareto diagrams
}

\author{
Diana Germanova-Krasteva ${ }^{1, *}$, and Irena Dimcheva ${ }^{2}$ \\ ${ }^{1}$ Technical University of Sofia, Textile Department, 8, Kl. Ohridski Blvd, Sofia, Bulgaria \\ ${ }^{2}$ Grammer AD, 2, Tsar Osvoboditel Str, Trudovets, Bulgaria
}

\begin{abstract}
The Pareto diagram is a powerful tool for identifying the significant factors influencing objects, processes, services, etc. In the production sphere, it is very suitable for analysis of defects and their impact. In this work are summarized the types of defects that occur in the production of headrest covers for car seats. Analysis was made of both the frequency of occurrence of defects and the financial losses from them. The research is done on the whole production range (all projects) proceeded in a given month, on product families and on specific products. The three defects with the highest frequency of occurrence were identified. For them, additional study was conducted to determine the impact of the type of used material on internal scrap calculated as an expense in euros.

Based on the obtained results, recommendations are made for improving the work and its results.
\end{abstract}

\section{Introduction}

The Pareto principle states that for many events roughly $80 \%$ of the effects come from $20 \%$ of the causes. It is named after the Italian economist Vilfredo Pareto, who has found that approximately $80 \%$ of the land in Italy was owned by $20 \%$ of the population. He has also established that the same proportion is valid for the distribution of income and wealth among the population. As a principle it is introduced by the management guru Joseph M. Juran who has proved that many natural phenomena are subordinated to the proportion 80/20 - economics, sociology, computing, sports, etc.

Widely used is the Pareto diagram, which is a cumulative curve giving the relationship between the cumulative frequency and the individual factors ranked according to the frequency of their occurrence or degree of influence. It is one of the Ishikawa's seven basic tools for quality management [1].

For example, on Fig. 1 is given a Pareto diagram presenting the most used raw materials that are dyed in Turkey [2].

As seen from the diagram, the mixture Wool/Polyester forms $42.2 \%$ of the total production, followed by pure Wool $(30.8 \%)$ and Wool/Nylon (16.5\%). The remaining materials constitute $10.5 \%$ of the production that is less than $20 \%$. This means that 3 materials form over $80 \%$ of the total quantity of dyed materials.

\footnotetext{
* Corresponding author: dianakra@tu-sofia.bg
} 


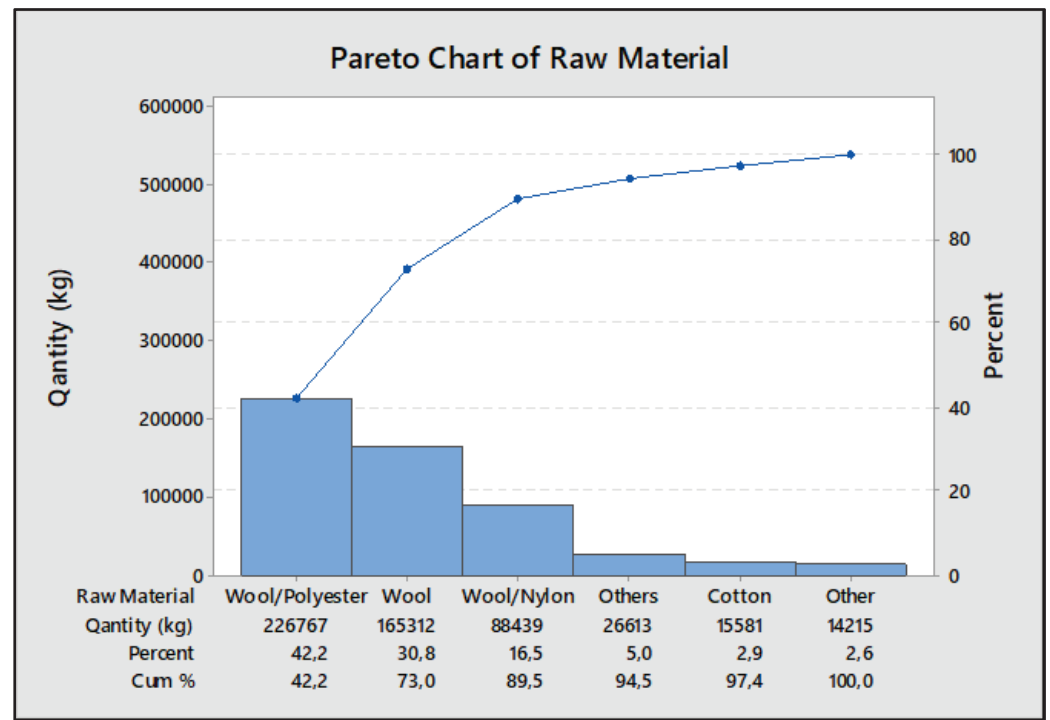

Fig. 1. Pareto diagram of raw material quantities [2].

In the production sphere, it is often used as a tool for quality management, especially for analysis of defects and their impact.

In [3] is carried out an investigation on the application of different techniques like Pareto chart, Ishikawa's fish bone diagram and Six Sigma for quality control of knitted fabrics. In Fig. 2 are shown the results from the Pareto analysis.

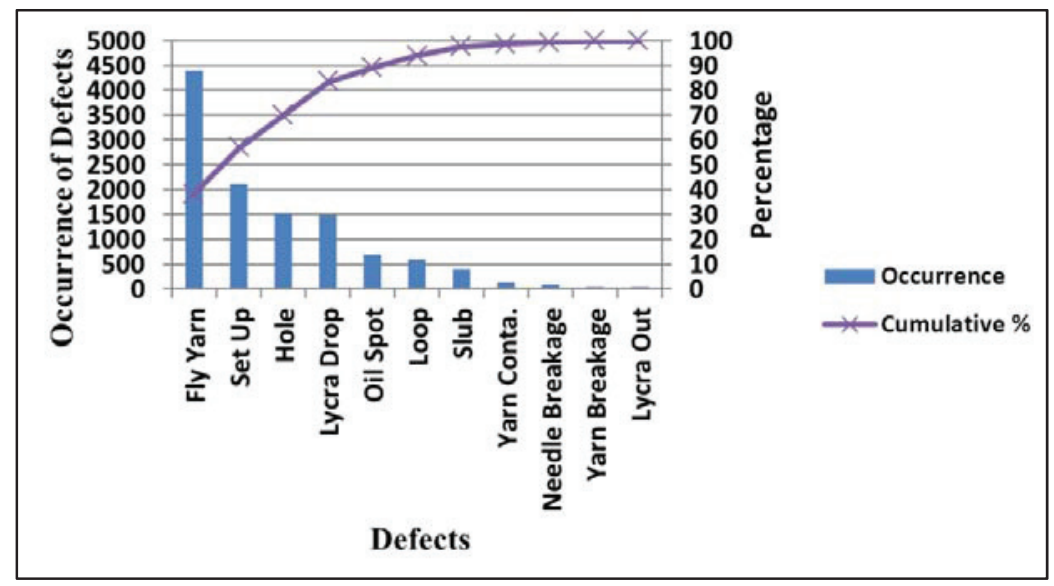

Fig. 2. Pareto chart for identifying major defects [3].

From 10 investigated defects 7 are responsible for $95.56 \%$ of total defects. They are arranged and included in the presented Pareto chart. Four of them form over $80 \%$ of all faults.

A lot of other examples can be given as good practices for defect analysis of different textiles and clothing [4-7].

This article presents the results of a study, which aims to analyse the defects that occur in the production of headrest covers by using the Pareto diagram (chart). 


\section{Experimental}

The study was conducted in Grammer AD, Bulgaria. The object of investigation is the production of rear middle headrest (Fig. 3).

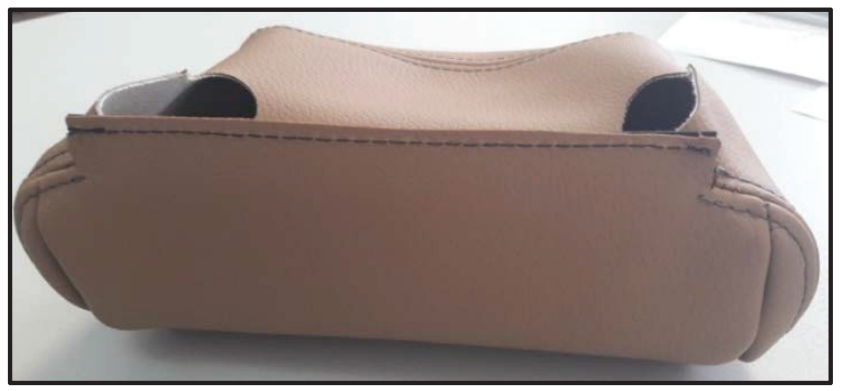

Fig. 3. Picture of a finished headrest G3Y for BMW.

\subsection{Defects' Classification}

Based on the analysis of the production technology and the identified defects, a classification was performed. The results are summarized in Table 1.

Table 1. Classification of the defects.

\begin{tabular}{|c|c|c|c|}
\hline № & Defect & № & Defect \\
\hline 1 & $\begin{array}{l}\text { Non-compliant seam width due to } \\
\text { wrong placed guide }\end{array}$ & 16 & Improperly cut salvage \\
\hline 2 & Needle caused defect & 17 & $\begin{array}{l}\text { Improperly positioned decorative } \\
\text { versus functional seam }\end{array}$ \\
\hline 3 & Seam puckering & 18 & Visible holes from processing \\
\hline 4 & Technological defect & 19 & $\begin{array}{l}\text { Improper seam width at the end } \\
\text { hindering the next operations }\end{array}$ \\
\hline 5 & Improperly positioned plastic border & 20 & $\begin{array}{l}\text { Incorrect seam width when joining the } \\
\text { central with the side details }\end{array}$ \\
\hline 6 & $\begin{array}{l}\text { Wrong plastic border (for another } \\
\text { product) }\end{array}$ & 21 & $\begin{array}{l}\text { Improperly performed back-tack at the } \\
\text { beginning and end of the decorative } \\
\text { seam }\end{array}$ \\
\hline 7 & Wrong or wrong positioned label & 22 & Loose decorative seam \\
\hline 8 & Wrong number of back-tack stitches & 23 & $\begin{array}{l}\text { Dropped or shifted decorative stitch in } \\
\text { the upper headrest turns Non-smooth } \\
\text { double decorative seam }\end{array}$ \\
\hline 9 & Uneven width of the closing seam & 24 & $\begin{array}{l}\text { Damaged skin by joining the central } \\
\text { and side parts }\end{array}$ \\
\hline 10 & $\begin{array}{l}\text { Non-compliant stitch length of the } \\
\text { closing seam }\end{array}$ & 25 & $\begin{array}{l}\text { Visible back-tack - loose or not "stitch } \\
\text { in stitch" }\end{array}$ \\
\hline 11 & Wrong positioned V-notches & 26 & $\begin{array}{l}\text { Incorrect stitch length due to } \\
\text { imprecisely executed seam in the turns }\end{array}$ \\
\hline 12 & $\begin{array}{l}\text { Uneven material distribution in the } \\
\text { closing seam }\end{array}$ & 27 & Visible holes from rework \\
\hline
\end{tabular}




\begin{tabular}{|c|l|c|l|}
\hline 13 & $\begin{array}{l}\text { Improper positioning (misalignment) of } \\
\text { the details in the closing seam }\end{array}$ & 28 & $\begin{array}{l}\text { Improper tension of the decorative } \\
\text { seam thread }\end{array}$ \\
\hline 14 & Improper sewing thread tension & 29 & Material defect (fault of the supplier) \\
\hline 15 & Non-smooth turn areas & \multicolumn{2}{|l}{} \\
\cline { 1 - 2 }
\end{tabular}

\subsection{Cost Analysis of the internal scrap by projects}

The first step was identifying the projects that realize the biggest losses from scrap. Initially, the research was not focused on the amount of scrap as a number of defective products, but on the projects that generate the largest financial losses.

In Table 2 is given a reference for the internal scrap for October 2019. The total amount of loses is $€ 40929$.

Table 2. Losses from internal scrap for October 2019.

\begin{tabular}{|c|c|c|c|c|}
\hline № & Project & Internal scrap, $€$ & $\begin{array}{l}\text { Relative share } \\
\text { (frequency), \% }\end{array}$ & $\begin{array}{c}\text { Cumulative } \\
\text { frequency, \% }\end{array}$ \\
\hline 1 & Daimler BR $213 \mathrm{KS}$ & 12857 & 31 & 31 \\
\hline 2 & BMW G3Y & 7969 & 19 & 50 \\
\hline 3 & JLR & 7467 & 18 & 68 \\
\hline 4 & BMW L6 & 3358 & 8 & 77 \\
\hline 5 & VW 48X & 1836 & 4 & 81 \\
\hline 6 & F07 & 1334 & 3 & 84 \\
\hline 7 & BMW F4x & 1047 & 3 & 87 \\
\hline 8 & BMW F10 & 859 & 2 & 89 \\
\hline 9 & VW WOKS I_II & 535 & 1 & 90 \\
\hline 10 & VW 359 & 519 & 1 & 92 \\
\hline 11 & Other & 3417 & 8 & 100 \\
\hline & Total scrap, $€$ & 40929 & & \\
\hline
\end{tabular}

A statistical analysis of the data was made and a Pareto diagram was drawn, which is presented in Fig. 4.

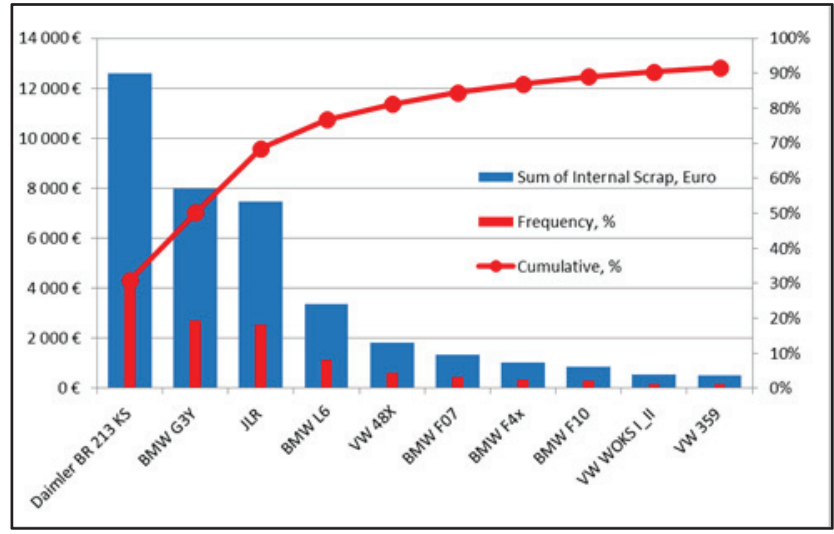

Fig. 4. Losses from internal scrap by projects

The graph shows that the leading projects in terms of scrap losses are Daimler BR213KS, followed by BMW G3Y and JLR. These are the projects with the most 
expensive products and even with a small amount of discarded products, the losses are high.

\subsection{Cost Analysis of the internal scrap by product families}

A project consists of several different product families. Although the same materials are used for their production (the products from each family are installed together in the car), they have a different design and shape. This predetermines the appearance of different defects with different frequency of occurrence. It is possible that in a specific project only one of the product families has a high level of scrap, and the rest are produced with acceptable technological scrap $(\leq 1 \%)$.

Table 3 presents the collected data on the expenses of internal scrap by product families. In Fig. 5 they are ranked by size.

Table 3. Losses from internal scrap by product families.

\begin{tabular}{|c|c|c|c|c|}
\hline № & Project & $\begin{array}{l}\text { Internal } \\
\text { scrap, } €\end{array}$ & $\begin{array}{l}\text { Relative share } \\
\text { (frequency), \% }\end{array}$ & $\begin{array}{l}\text { Cumulative } \\
\text { frequency, } \%\end{array}$ \\
\hline 1 & Daimler BR $213 \mathrm{KS}$ front headrest cover & 6470 & 16 & 16 \\
\hline 2 & $\begin{array}{l}\text { BMW G3Y HIMI rear centre headrest } \\
\text { cover }\end{array}$ & 6390 & 16 & 31 \\
\hline 3 & $\begin{array}{l}\text { Daimler BR } 213 \text { KS Hi rear headrest } \\
\text { covers }\end{array}$ & 6117 & 15 & 46 \\
\hline 4 & BMW G11 Vo front headrest cover & 4151 & 10 & 57 \\
\hline 5 & BMW G11 Hi rear armrest cover & 3818 & 9 & 66 \\
\hline 6 & BMW L6 front headrest cover & 3358 & 8 & 74 \\
\hline 7 & BMW F4x armrest cover & 1836 & 4 & 79 \\
\hline 8 & BMW F07 front headrest cover & 1334 & 3 & 82 \\
\hline 9 & JLR X760 Hi rear centre headrest cover & 1076 & 3 & 84 \\
\hline 10 & BMW F07 rear headrest covers & 1047 & 3 & 87 \\
\hline 11 & BMW F10 front headrest cover & 859 & 2 & 89 \\
\hline 12 & VW WOKS I II front headrest cover & 535 & $\frac{2}{1}$ & 90 \\
\hline 13 & VW 359 front headrest cover & 519 & 1 & 92 \\
\hline 14 & Other & 3417 & 8 & 100 \\
\hline & Total scrap, $€$ & 40929 & & \\
\hline
\end{tabular}

Project BMW G3Y appears again in the first positions with one of its product families BMW G3Y HIMI cover for rear middle headrest. It includes products made from leather (Dakota, Saddle and Merino), which are expensive materials.

\subsection{Analysis of the defects by projects}

For all projects an analysis of the defects with respect to their origin was made. Defects are categorized into four major groups: in decorative seam, in closing seam, from preparatory operations (overlock and plastic borders) and material based.

In Table 4 are presented the losses for product family BMW G3Y HIMI cover for rear middle headrest.

In Fig. 6 are presented the losses by the origin of the defect. The predominant defects are in decorative seam that defines the good appearance of the product. 


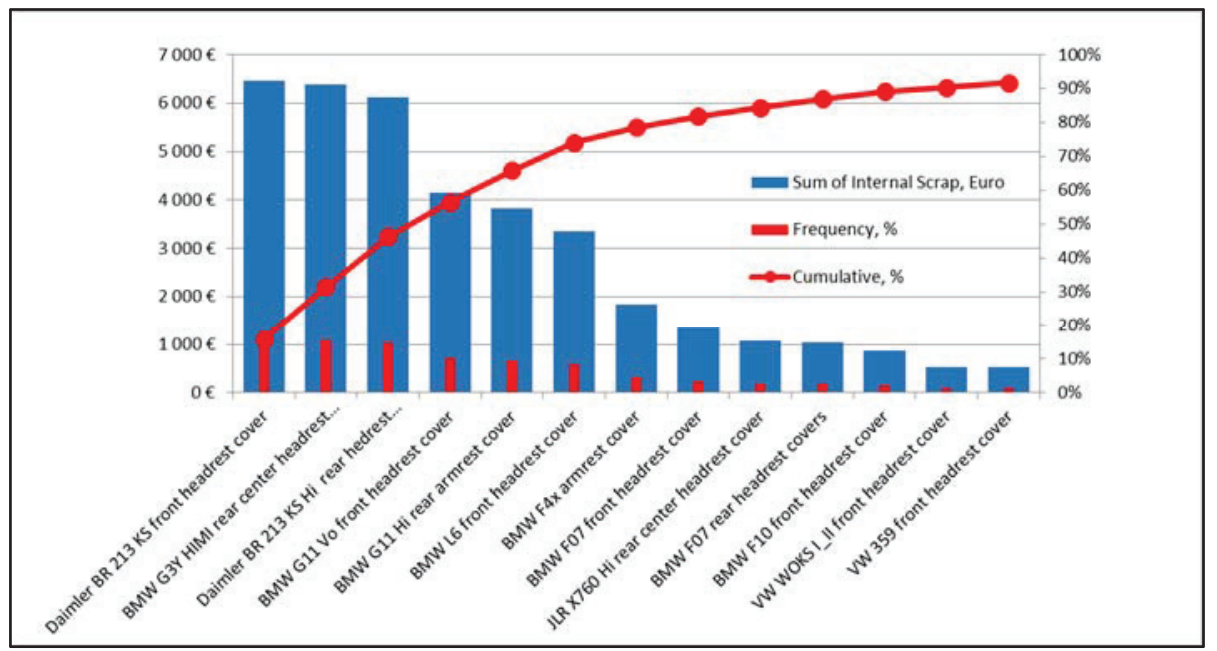

Fig. 5. Losses from internal scrap by product families.

Table 4. Losses from internal scrap for product family BMW G3Y HIMI cover for rear middle headrest.

\begin{tabular}{|c|c|c|c|c|}
\hline № & Project & $\begin{array}{l}\text { Internal } \\
\text { scrap, } €\end{array}$ & $\begin{array}{l}\text { Relative share } \\
\text { (frequency), \% }\end{array}$ & $\begin{array}{r}\text { Cumulative } \\
\text { frequency, \% }\end{array}$ \\
\hline 1 & Decorative seam & 3392 & 53 & 51 \\
\hline 2 & Material & 2000 & 31 & 84 \\
\hline 3 & Closing seam & 805 & 13 & 97 \\
\hline 4 & Preparatory operations & 193 & 3 & 100 \\
\hline & Total scrap, $€$ & 6390 & & \\
\hline
\end{tabular}

Significant is the share of losses caused by defect materials. In this case, the supplier is notified in a timely manner and bears the cost of the scrap. It is his commitment to take actions to ensure that the subsequent deliveries will meet customer requirements and quality standards.

The other two groups of defects have less impact, as can be seen in Fig. 6.

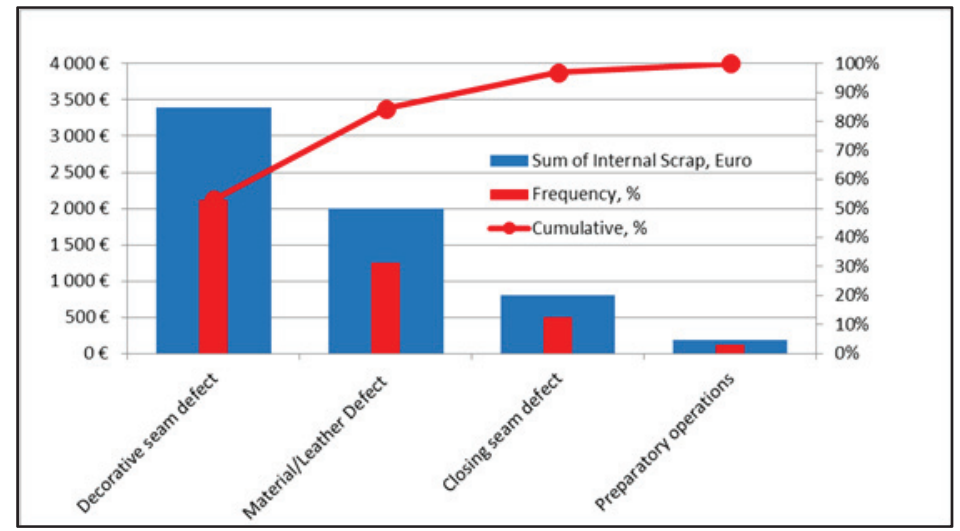

Fig. 6. Losses from internal scrap depending on the origin of the defect. 
The analysis of the financial losses specifies these projects and product families to which efforts for quality improving should be directed.

\subsection{Analysis of the defects for the product family generating the largest losses from scrap}

As a next step, a Pareto analysis of the product family with the biggest losses (BMW G3Y HIMI cover for rear middle headrest) was performed.

A control card has been developed, in which for each defect from Table 1 the number of discarded details per day is recorded and a summary for a month was made.

After processing the results, the Pareto diagram is drawn, presented in Fig. 7.

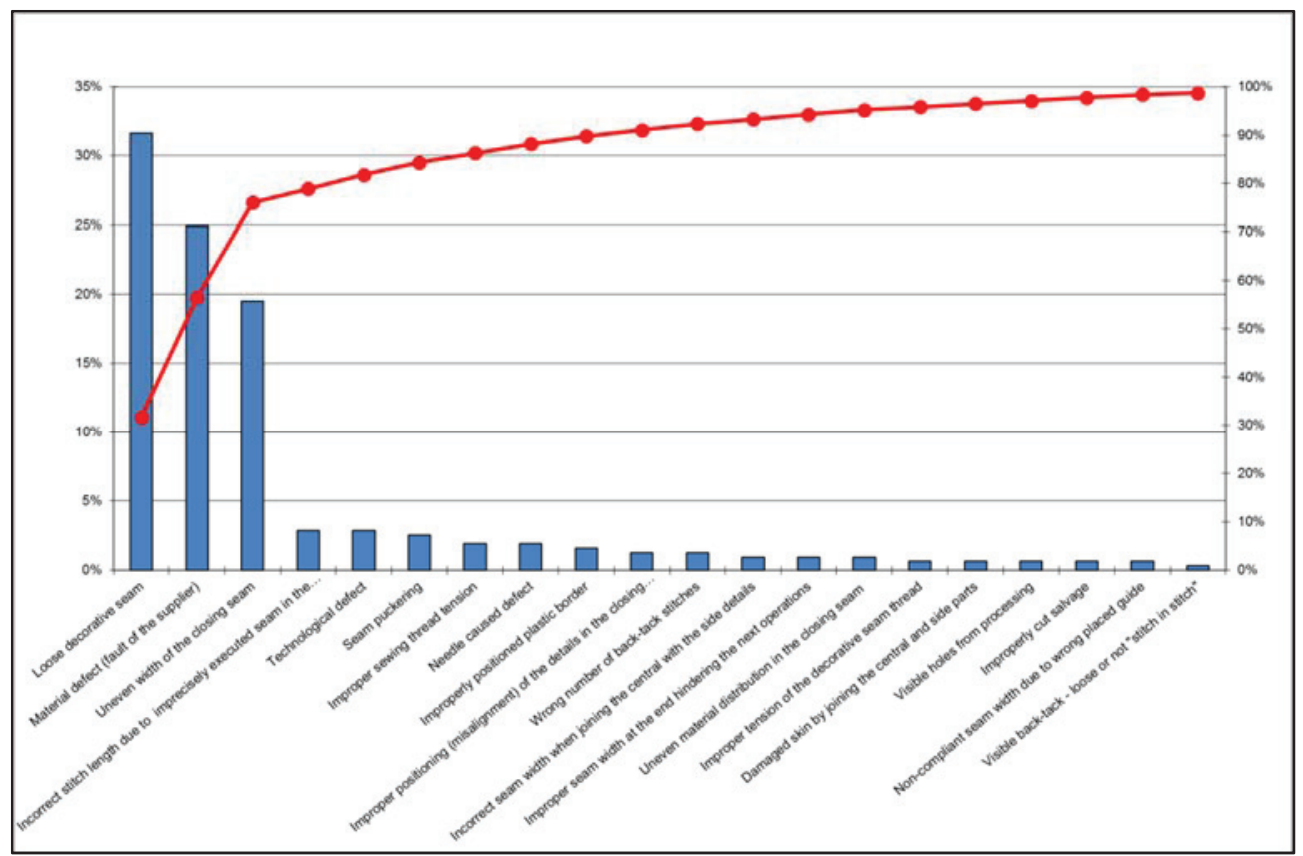

Fig. 7. Pareto diagram of defects in a product family BMW G3Y HIMI cover for rear middle headrest.

The diagram shows that the first three defects stand out sharply: Loose decorative seam - $32 \%$ of the total number of all rejected products, Material defect (defect not found on Incoming control and admitted to the production line) - $25 \%$ and Uneven width of the closing seam $-19 \%$.

These three defects form $76 \%$ of the product family's scrap.

\subsection{Analysis of products discarded due to Loose decorative seam}

This defect was found in eleven products. The Pareto chart with the number of defects in each material is shown in Fig. 8.

The first three materials form over $50 \%$ of the total number of detected defects. The first commodity number is made of leather Saddle, followed by covers made of artificial leather and leather Merino. The behaviour of all three materials during the sewing process was analysed. The feedback of the operators who sew a double decorative seam 
was taken into account; the qualitative criteria for a decorative seam and the admissible tolerances were discussed. On the recommendation of the technologist, additional training was made for certain operators who make the most mistakes in the sewing process.

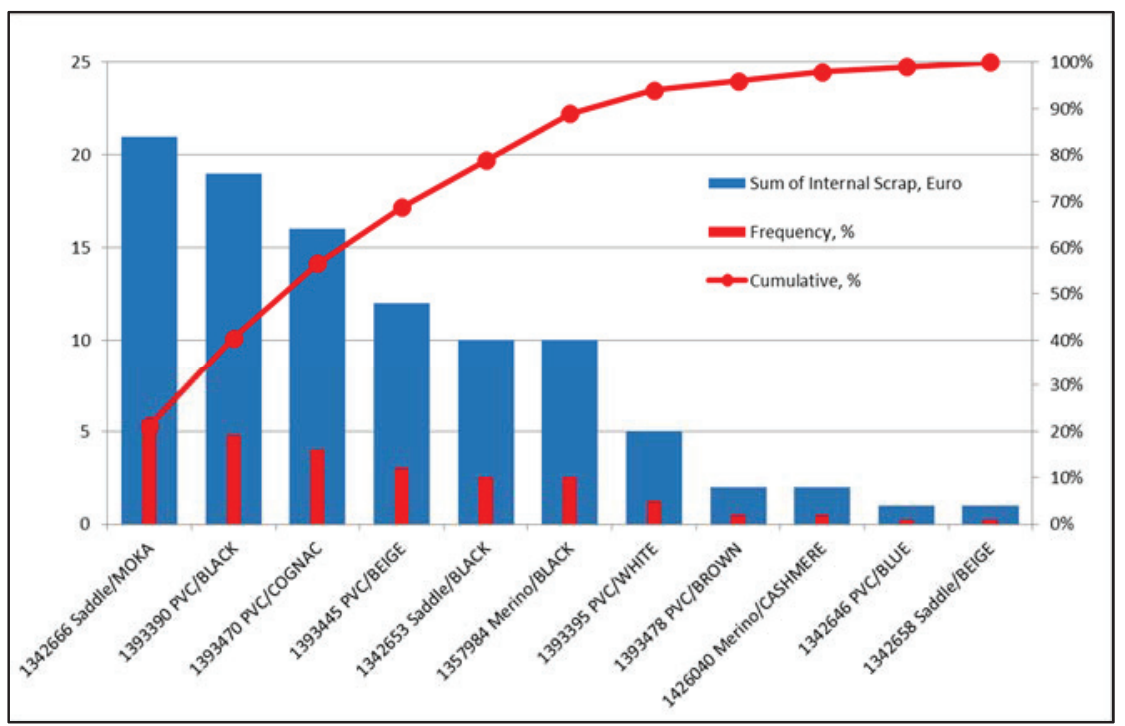

Fig. 8. Pareto diagram by product due to Loose decorative seam

\subsection{Analysis of products discarded due to Material defect}

Four products have shown such a defect. $64 \%$ of all discarded products belong to only one product number (Fig. 9). This information was sent to the supplier in order to take measures and strengthen the Outgoing quality control. As an internal measure, Grammer AD has appointed a $100 \%$ inspection of each item of this commodity number.

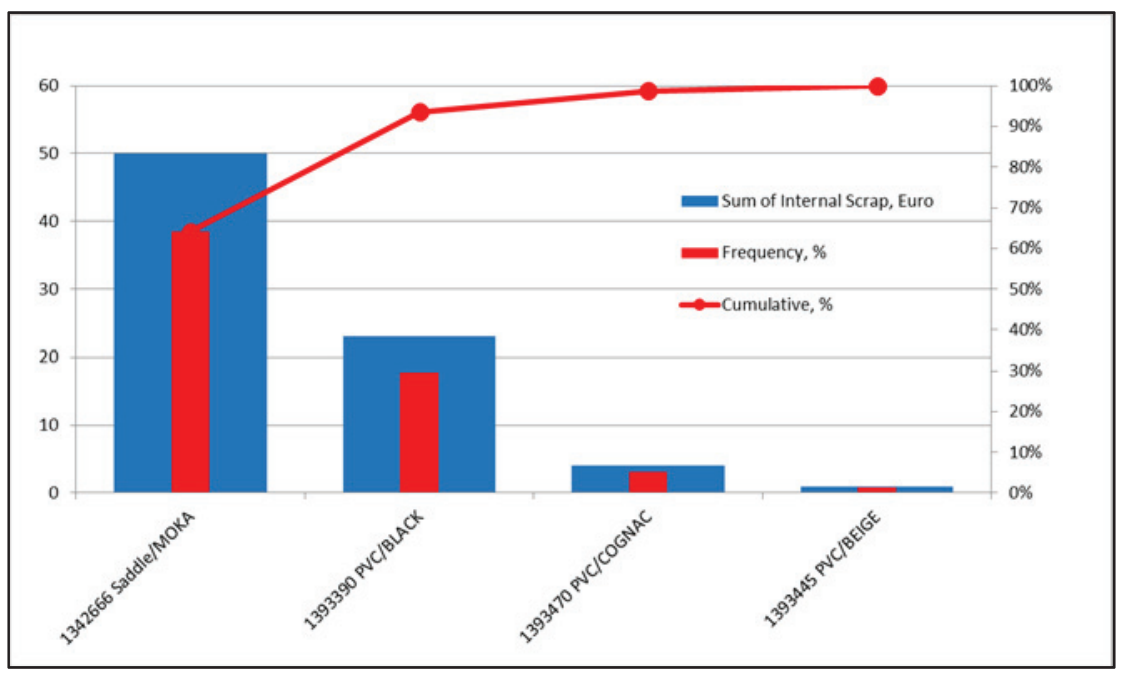

Fig. 9. Pareto diagram by product due to Material defect. 


\subsection{Analysis of products discarded due to Uneven width of the closing seam}

The correct execution and observance of the closing seam parameters is extremely important, because the double decorative seam passes along its contour. Its production is a challenge, as the rear middle headrest covers are made of small details with a complex design. They have four "turns" that follow the shape of the headrest.

The information for items discarded due to a defect in the closing seam has been taken from the database. The data was processed and the obtained Pareto diagram can be seen in Fig. 10.

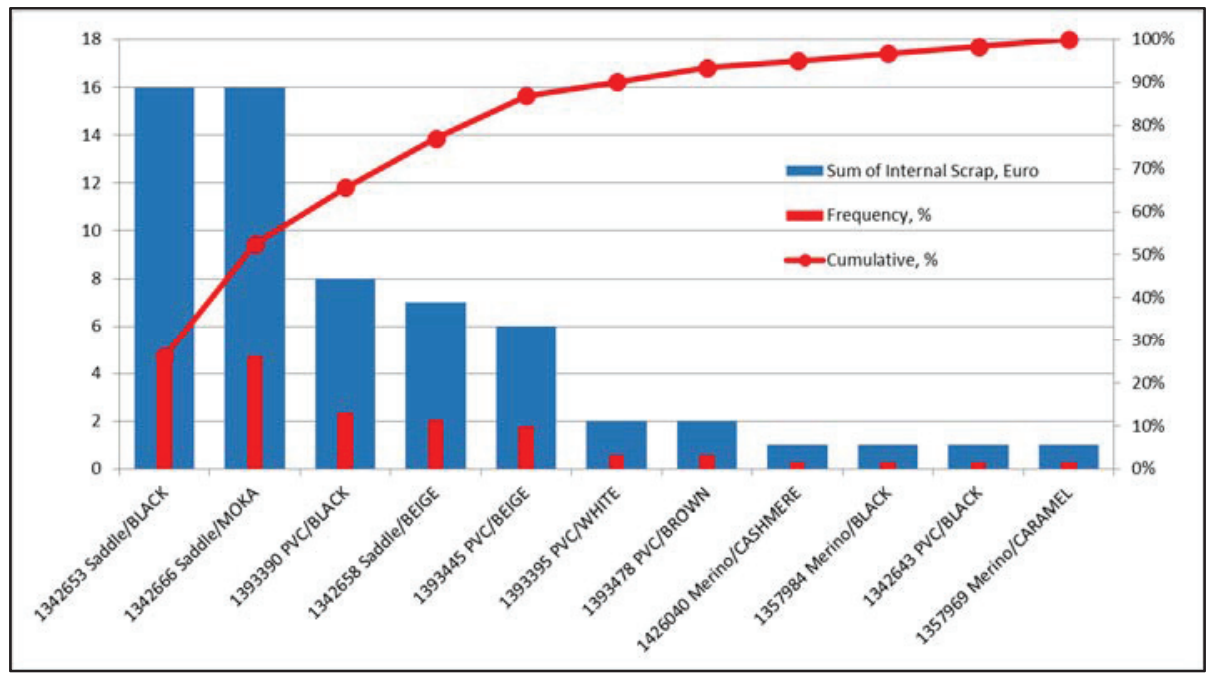

Fig. 10. Pareto diagram by products due to defects in the closing seam.

The Pareto diagram shows that most mistakes in performing the closing seam operation are made when processing Saddle leather. 63\% of all discarded cases for the month are made of this material, which requires immediate corrective action. For performing this operation have to be chosen good operators. It is possible even to be revised the standard time for executing this operation.

\section{Conclusions}

Based on the performed research, the following conclusions can be made:

$\checkmark$ The possible defects in the production of headrest covers for car seats are systematized.

$\checkmark \quad$ The data on internal scrap for all "projects" worked in a given month at Grammer $\mathrm{AD}$ is collected and summarized. Based on the Pareto diagram, an analysis was made of the projects that generate the largest losses from scrap.

$\checkmark$ All projects consist of several different product families. Pareto diagram was developed and the losses caused by production of scrap were analysed. The differentiation by product families reflects the design influence on the various defects and the frequency of their occurrence. The groups that form the highest expenses are identified. 
$\checkmark \quad$ Pareto diagram of the defects for all projects according to their origin is made and analysed. Defects are categorized into four main groups: decorative seam, closing seam, preliminary operations and material.

$\checkmark \quad$ Statistics on the number of defects by type in the production of the product family generated the highest losses have been collected. Pareto diagram is drawn for the relative and cumulative frequency of defects, identifying the significant and insignificant defects according to their number.

$\checkmark \quad$ The main defects of the studied product family are:

- Non-smooth/loose double decorative seam with a relative share of $32 \%$;

- Material defects not detected during Incoming control, with a relative share of $25 \%$

- Uneven width of the closing seam - $19 \%$.

$\checkmark$ For these three defects, diagrams and in-depth analyses have been made of the impact of the type of material used on the internal marriage, calculated as costs in euro.

$\checkmark$ Based on the obtained results, recommendations for necessary measures have been made.

\section{References}

1. G. Kamiske, J.-P. Brauer. Qualitätsmanagement von A bis Z, Karl Hanser Verlag, (1993).

2. U. İnce, B. Ayvaz, F. Öztürk, A. O. Kuşakcı, Journal of International Trade, Logistics and Law 4, 117 (2018)

3. Sh. Sadi, S. Rahman, Textile Today 3 (2016)

4. Sh. Sadi, N. Nahar, Sh. Hossain, S. H. Sajib, American Journal of Materials Science 8(1), 6-14 (2018)

5. T. Ahmed et al, International Journal of Modern Engineering Research 3(6), 37003715 (2013)

6. T. Islam, International Journal of Scientific \& Engineering Research 8(7), 1885-1890 (2017)

7. https://onlinegarmentsacademy.blogspot.com/2019/04/pareto-analysis-fishbonediagram-garments.html, Accessed on date 30 October, 2020 